Code Choice Used in YouTube Content "Nebeng Boy"

Caecilia Ivana Angelia V.

Universitas Sebelas Maret, Surakarta, Indonesia

Author Note

${ }^{1}$ Author is student of English Department, Faculty of Cultural Sciences, Universitas Sebelas Maret, Jalan Ir. Sutami 36A, Surakarta, Indonesia 
Nebeng Boy is one of the most popular YouTube content created by Indonesian YouTuber and an ex-Video Jockey from MTV, Boy William. The participants in this YouTube content are divided into two; the Host and the Guests. This research aims to find out the code choices chosen by the participants of YouTube content "Nebeng Boy" and the reasons why the participants choose the different codes. This research is a case study of sociolinguistics which employed a descriptive qualitative method. The data are collected through observing the conversation, transcribing the dialogues between participants, and classifying the data. The researcher used total sampling technique and took the whole part of dialogue from six videos of "Nebeng Boy". The results show that the code choices employed by the participants of Nebeng Boy are informal variety from Bahasa Indonesia and English which resembles of high social class or high social status. Each participant has different way in using the codes and also has different reason behind it. The Host of the program uses informal Bahasa Indonesia to show solidarity, express emotions, show intimacy, changing topics, and including another person to the conversation. Meanwhile, the factors that the guests use the code choices are the background of the person, the profession, function of the conversation, topics, the situation of conversation, and to include another person.

Keywords: code choice, YouTube, interview, Sociolinguistics, Linguistics 
CODE CHOICE USED IN YOUTUBE CONTENT

Code Choice Used in YouTube Content "Nebeng Boy"

YouTube is one of widely used social media in Indonesia since 2006. Created by Chad Hurley, Steve Chen, and Jawed Karim, YouTube users have increased drastically. YouTube has made many awards and collaborations with big companies in America including the nickname "Nine of ten best products" in 2006. Unlike other social media, YouTube is a free video-sharing platform which allows people to make money from getting many subscribers and viewers of their content.

Today, a lot of people make their own YouTube channel and start uploading their content to YouTube. The theme of the content is varied, people can upload videos about their daily activities, video review products or services, video of mini drama, tutorials, or even lectures. There is also no limitation for people about their age, gender, nationality, or language he or she speaks to start uploading content.

YouTubers who make quality content get income from advertisement Google AdSense and or do collaborations with some companies by doing endorsement or product placement in their content. The more quality and attractive the content, the more people will be interested in subscribing and the company will also pay attention to their channel to make some collaboration. Some use certain language, accent, dialect or style of a language that they think suitable and interesting to watch. For example: people who share makeup or beauty tutorial videos (in here called Beauty Vlogger) uses Bahasa Indonesia mixed with English. They might do that due to lack of makeup terms in Bahasa Indonesia, or they might only do that so that they might sound expert in what they do, or other reasons. A lot of cases happen not only by Beauty Vloggers, but also the gadget or car reviewers, video tutorials, or just the normal vloggers.

Boy William started uploading YouTube video since May 10th, 2017. The total videos in his channel are 61 per April 2019 and with 1,1 million subscribers he makes 


\section{CODE CHOICE USED IN YOUTUBE CONTENT}

around 33 million rupiahs per month from YouTube. Nebeng Boy is the most-watched YouTube content of Boy William's channel. Some of the videos of Nebeng Boy have been watched two until three million times. This content is about car interview themed video where Boy William (as the host) picks up the guest or the interviewee and drive to unspecific destination to just asking them casual questions. This is an imitation of James Corden's videos called “Carpool Karaoke”.

The most interesting aspect of this content is Boy William's success in inviting people from different professions and backgrounds to participate in his program, starting from his fellow celebrity friends, presenter, comedian, gamers, even the President of Republic Indonesia, President Jokowi. Although Boy William as the host of the program interviews a lot of people, he tries to make the atmosphere casual and the impression of closeness with the guests. In this case, Boy William shows different way of talking based on the guest he is having in his car.

The codes appeared in Nebeng Boy vary. Both formal and informal language are used in the conversations. The choices of language expressions are different for each participants of Nebeng Boy, it may depend on a few components such as the person who is talking, the setting, the topic and the function of the conversation itself (see Holmes, 1992).

When Boy William are driving, Daniel Mananta uses a less formal way of talking, Boy William sometimes also uses Indonesian slangs such as "Gue" and "Lo" for the substitute of "Me" and "You" to create a sense of closeness with the guests. In bahasa Indonesia, people in peers change their nickname or way of calling someone with less formal to show their relationship (how close they are to each other, or to show respect for someone who is older, or someone who has higher status with them). Opposite to when he is talking to Najwa Shihab, he calls her "Kak Najwa" (a person who is older than the speaker) rather than calling her by her name or by "Lo" to create a sense of closeness 


\section{CODE CHOICE USED IN YOUTUBE CONTENT}

between him and Najwa Shihab without losing a sense of respect. He does not choose to call "Ibu" or "Bu" which means "Madam" or "Ms" to Nawja since it can create distance between the host and the guest. When Boy William has President Jokowi as his guest, he talks in Bahasa Indonesia and barely inserts English words or switches from Bahasa Indonesia to English as he often does to speak with other guests. From his conversation with President Jokowi, even though Boy William still addresses President Jokowi with "Bapak" which means "Sir" in English, Boy William still uses informal or nonstandardized Bahasa Indonesia at times.

A speaker always concerns to use of language by following the rules of what is appropriate using the language. The emergence of the language choice itself is natural, automatic, and unplanned (Yusmawati, 2018). The choice of language is not limited only by just the person he or she is talking to, but also by the topic they are talking about, where and when the conversation is conducted, and what media used to carry the conversation.

Holmes (2006) explained the relationship between the linguistic phenomenon and the social factors in choosing a language with domain study. The domain of a language is the participant, setting, and topic (Holmes, 2006, p. 22). According to Fishman (1972) domain is also an institutional context for language use, congruent behavioral and cooccurrence. Domain can be family, religion, employment, friendship, and education.

There are many researchers conducted to study the effectiveness of YouTube, however, only few researches focus on studying linguistics aspects of YouTube users. Some of the researches only study he code switching used in YouTube content, for example, research by Lailatul Maghfiroh with the title "An Analysis on Form, Function, And Reason of Code-Switching and Code-Mixing Used in Vlog of Shirin Al Athrus" in 2018. Maghfiroh in her research examines the type and form of code switching and code mixing, the function of code switching and code mixing, and also the reason why the 


\section{CODE CHOICE USED IN YOUTUBE CONTENT}

speaker uses the code switching and code mixing.

Similar researches also conducted by Atria Primayanda in 2018 with title "The Role of Code-Switching Phenomena in a YouTube Vlog by Sacha Stevenson" and by Dhia Salsabila the thesis of "An Analysis of Code Switching used by Beauty Vlogger "Sarah Ayu" in Video "Testing Full Face of New Makeup" in 2018. The three of the research above are examined just about the types and the reasons of the code switching are used in the videos.

The purposes in this research are to find out the code choices used by the participants, to find out the characteristic and why the participants chose different code choices. In finding out the

\section{Method}

This research is a case study with descriptive qualitative method. Qualitative method is appropriate for this research because it is useful to gather and analyse explanatory data such as exploring the context where the Code Choice takes place in the YouTube content. In collecting the data, the researcher has done a few techniques namely taking notes from observing the conversation, transcribing the dialogues between participants, and classifying the data. Total sampling technique is chosen because the target or the population is small and the characteristics are well-defined. The researcher took the whole part of the dialogue from six videos of "Nebeng Boy". It is done by taking notes and transcribing the videos of Nebeng Boy.

\section{Results}

\section{Code Choices}

There are several code choices occurs in Boy William's YouTube content 'Nebeng Boy'. The codes employed by the participants in the videos are varied, depending on the 


\section{CODE CHOICE USED IN YOUTUBE CONTENT}

topics, situation and the participants itself, that will later on be explained on the next part of the reason why the participants chose the code.

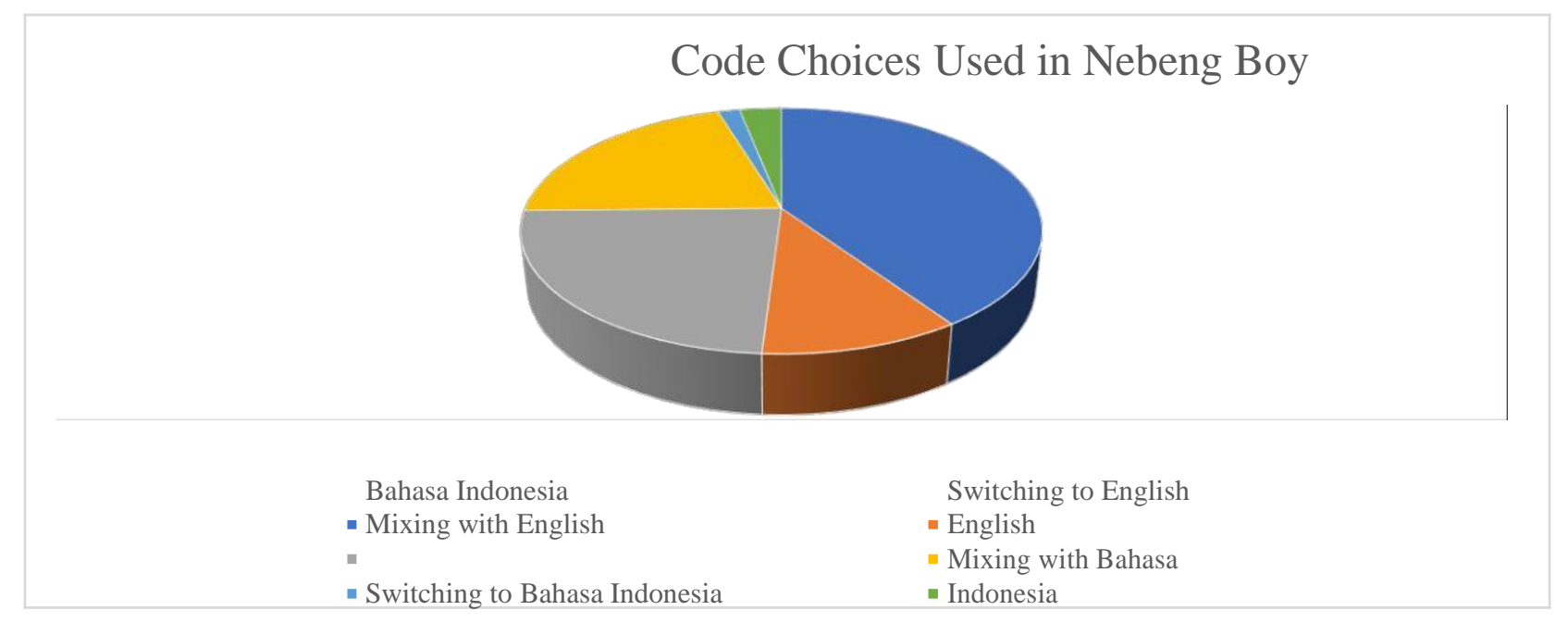

From the Figure 1. Code Choices Used in Nebeng Boy, the most common code chosen by the participants is Bahasa Indonesia (40,5\%), followed by Switching from Bahasa Indonesia to English (10,5\%) and mixing with English 23,7\%. Participants of Nebeng Boy rarely use English as the main language, therefore, English is only used 20,6\% followed with Switching from English to Bahasa Indonesia $(1,6 \%)$ and mixing with Bahasa Indonesia 3,1\%. The language varieties are used by each participant based on some motives. The explanation of each code choice are as follows:

1) Bahasa Indonesia

Bahasa Indonesia is national language of Indonesia. However, there are two categories of Bahasa Indonesia. First is Formal Bahasa Indonesia which marked with certain characteristic such as grammatical characteristic and words choice. Formal Bahasa Indonesia uses standard words which based on Bahasa Indonesia's principle in Pedoman Umum Ejaan Bahasa Indonesia yang Disempurnakan (EYD) and Kamus Besar Bahasa Indonesia. However, the use of Formal Bahasa Indonesia is not as much as Informal Bahasa Indonesia. Formal Bahasa Indonesia is only used in the written form or in written 


\section{CODE CHOICE USED IN YOUTUBE CONTENT}

speech such as speech and news report.

In this study, the researcher only found Informal Bahasa Indonesia because none of the participants use Formal Bahasa Indonesia during the conversation in Nebeng Boy. Informal Bahasa Indonesia is used by almost of all participants of Nebeng Boy except Austin Mahone because Austin Mahone is an American singer.

The Informal Bahasa Indonesia used by the participants is marked by the use of non-standardized words, incomplete grammatical sentence, and the use of local dialect. For example, in the conversation between Boy William and Najwa Shihab, in the opening part, Boy William said "it's challenging getting you in the car! Tau gak, banyak orang yang bilang 'Lu bakal ditolak! Dia mah gak bakal mau naik mobil lu!'”. In that part of dialogue, Boy William switched at intra sentential to English, and followed by Informal Bahasa Indonesia. "Tau gak, banyak orang yang bilang" means "Do you know, there are a lot of people said" is informal Bahasa Indonesia because in Formal Bahasa Indonesia Boy William should use "Tahu tidak, banyak orang berkata" because the word 'gak' is informal form of "tidak" and the word 'bilang' is informal form of 'berkata' and the last sentence “Lu bakal ditolak! Dia mah gak bakal mau naik mobil lu!" which means "You will be rejected, she wouldn't get into your car!" should be "kamu pasti ditolak! Dia tidak mungkin ingin naik mobil kamu!". The word "Lu" or means 'you' in English should be replaced with ' $k a m u$ ' if the relationship between speakers are close, or 'engkau' or 'anda' if the relationship between speakers are not close.

\section{2) English}

English is the least dominant language chosen by the participants. The only guests who speaks English the entire time is only Austin Mahone. Similar to the varieties of Bahasa Indonesia found by the researcher from the data, there are also varieties of English spoken by the participants. 
CODE CHOICE USED IN YOUTUBE CONTENT

Table 1

Percentage use of English in the Nebeng Boy

\begin{tabular}{|l|l|l|l|}
\hline \multirow{2}{*}{ Participants } & \multicolumn{2}{|l|}{ Variety of English } & \multirow{2}{*}{} \\
\cline { 2 - 4 } & SE & NSE & \\
\hline Boy William & $19(63,3 \%)$ & $11(36,7 \%)$ & $30(100 \%)$ \\
\hline Najwa Shihab & $1(100 \%)$ & 0 & $1(100 \%)$ \\
\hline Daniel Mananta & $2(100 \%)$ & 0 & $2(100 \%)$ \\
\hline Austin Mahone & $9(50 \%)$ & $9(50 \%)$ & $18(100 \%)$ \\
\hline Chelsea Islan & $2(100 \%)$ & 0 & $2(100 \%)$ \\
\hline$\sum$ & $33(62,3 \%)$ & $20(37,7 \%)$ & $53(100 \%)$ \\
\hline
\end{tabular}

$$
\begin{aligned}
& \mathrm{SE} \quad=\text { Standard English } \\
& \mathrm{NSE} \quad=\text { Non-standard English }
\end{aligned}
$$

There are two varieties of English found by the researcher from the dialogues on YouTube content 'Nebeng Boy'. The first variety is Standard English. This variety is marked by standardized grammatical sentence and standardized words which avoids nonstandard slangs and swear words. Standard English is associated with the prestige of the speakers within a language group (such as people in Britain) and is learnt by foreigners, and used in formal occasion, business, political situations, and mostly in mass media. Standard English may be used in daily spoken language however, the use may still depend on to whom the speaker talks to, time, place and situation of occurrence.

Meanwhile, the Non-standard English often found does not really pay attention to the standardized grammatical and the use of slang words or phrases. Non-standard English may have grammatical incorrect or incomplete, and it may consist of slangs and improvised personal opinions. People may use Non-standard English to colleagues, co-workers, siblings, and friends rather than to talk to people with higher social status or people who are older than the speaker. 


\section{CODE CHOICE USED IN YOUTUBE CONTENT}

3) Code Switching

In the data, there are also code switching found by the researcher done by the participants of Nebeng Boy. Code switching happens when the participants or the speakers change the language they speak whenever he or she has motivations to do so. The change of codes may happen between varieties within a language, codes, phrases, sentences, or even in a clause boundary. Code switching is found almost by each participant, except President Jokowi. President Jokowi does not switch from Bahasa Indonesia to English neither from English to Bahasa Indonesia.

Table 2

Percentage use of Code Switching in Nebeng Boy

\begin{tabular}{|l|l|l|l|}
\hline \multirow{2}{*}{ Participants } & \multicolumn{2}{|l|}{ Variety of Language } & \multirow{2}{*}{$\sum$} \\
\cline { 2 - 3 } & SWE & SWB & \\
\hline \hline Boy William & $11(78,6 \%)$ & $3(21,4 \%)$ & $14(100 \%)$ \\
\hline $\begin{array}{l}\text { Daniel } \\
\text { Mananta }\end{array}$ & $5(100 \%)$ & 0 & $5(100 \%)$ \\
\hline Najwa Shihab & $6(100 \%)$ & 0 & $6(100 \%)$ \\
\hline Austin Mahone & 0 & $1(100 \%)$ & $1(100 \%)$ \\
\hline Merry Riana & $3(100 \%)$ & 0 & $3(100 \%)$ \\
\hline Chelsea Islan & $2(100 \%)$ & 0 & $2(100 \%)$ \\
\hline$\sum$ & $27(87,1 \%)$ & $4(12,9 \%)$ & $31(100 \%)$ \\
\hline
\end{tabular}

SWE $=$ Switching to English

SWB = Switching to Bahasa Indonesia 


\section{CODE CHOICE USED IN YOUTUBE CONTENT}

The researcher found that Boy William as the host of the program switched from Bahasa Indonesia to English in the 9 data of 27, and switched from English to Bahasa Indonesia 2 times. Meanwhile the other participants only switched from their own vernacular language to English, and otherwise.

Most of the Code-Switching data found is Metaphorical Code Switching that will later on be explained based on each participant in the next part of the Chapter IV. This happens because most of the participants are alone only themselves in the car with Boy William and there are rarely change of situation in the program Nebeng Boy.

4) Code Mixing

Code Mixing is found $16,2 \%$ of the total data. This happens because majority of the participants are Indonesian and speak Bahasa Indonesia as their main language. However, there are data that shows that the participants are also mixing their Bahasa Indonesia with English in their conversation with Boy William in Nebeng Boy.

Table 3

Percentage use of Code Mixing in Nebeng Boy

\begin{tabular}{|l|l|l|l|}
\hline \multirow{2}{*}{ Participants } & \multicolumn{2}{|l|}{ Variety of Language } & \multirow{2}{*}{$\sum$} \\
\cline { 2 - 3 } & ME & MB & \\
\hline Boy William & $31(81,6 \%)$ & $7(18,4 \%)$ & $38(100 \%)$ \\
\hline $\begin{array}{l}\text { Daniel } \\
\text { Mananta }\end{array}$ & $5(83,3 \%)$ & $1(16,7 \%)$ & $6(100 \%)$ \\
\hline Najwa Shihab & $9(100 \%)$ & 0 & $9(100 \%)$ \\
\hline
\end{tabular}




\begin{tabular}{|l|l|l|l|}
\hline Merry Riana & $9(100 \%)$ & 0 & $9(100 \%)$ \\
\hline Chelsea Islan & $7(100 \%)$ & 0 & $7(100 \%)$ \\
\hline$\Sigma$ & $61(88,4 \%)$ & $8(11,6 \%)$ & $69(100 \%)$ \\
\hline
\end{tabular}

$\begin{array}{ll}\text { ME } & =\text { Mixing with English } \\ \mathrm{MB} & =\text { Mixing with Bahasa Indonesia }\end{array}$

From the table above, only Boy William and Daniel Mananta who mix both languages (English and Bahasa Indonesia). It may happen because code mixing became style of talking for Daniel Mananta and Boy William as an ex-VJ who were fluent speaking Bahasa Indonesia and English with the same competency.

Meanwhile, the other participants such as Najwa Shihab, Merry Riana, and Chelsea Islan only found to mix Bahasa Indonesia with English, but does not otherwise.

\section{The Reason Why the Participants use the different code choices}

The results shown by the findings of this research proves Fasold's theory in his book The Sociolinguistics of Society in 1984 which stated that the choice of language is not limited in choosing a whole language but also the variation in the same language, switching code, and mixing code. The most common code choice found in the videos analysed from Nebeng Boy is Informal Bahasa Indonesia. This code choice is used almost by all of the participants except Austin Mahone (an American Singer) which only speaks English. The other code choices appeared in the videos are Bahasa Indonesia mixing with English, switching to English, English, mixing with Bahasa Indonesia, and switching to Bahasa Indonesia.

The participants of Nebeng Boy always choose to use informal variety of languages, in Bahasa Indonesia and in English. This phenomenon is indicated by incomplete sentence structure, the use of informal words, phrases, and expression, and the mixing with another language. The switching or mixing with other language such as Bahasa Indonesia mixed with English happened when the participant needs of lexical substitution to express their opinion or feelings, meanwhile, switching 
from English to Bahasa Indonesia happened because of other party is included or to exclude other party.

The code choices chosen by the participants show that the use of English and Bahasa Indonesia became features of bilingualism. This matches Haugen's (1949) and Mackey's (1972) theory that if one person successfully gives a complete speech and expression with meaning or use two codes alternately is categorized as bilingual. In this case, bilingualism became the mark of elite community or high social class status shown by the guests of Nebeng Boy, and the host of Nebeng Boy itself.

Compared to the previous research about code choice in movie Eat, Pray, Love conducted by Reiza Fadhila in 2016, the code choice of the speaker was not explained in detail such as the indication of language variety but only discuss about the code switching, code mixing and the whole language use. However, the reason of choosing the code choice maybe similar to research conducted to Istrina's research about code choice in a movie entitled "Rush Hour 2" in 2010 which showed the results to show respect, to elaborate and emphasize the message, and to show intimacy, to avoid misunderstanding, and shows incompetency.

However, in choosing languages, each of the participants in Nebeng Boy may do it purposely and non-purposely. For example, Boy William always uses informal languages to his guests to show intimacy (Hughes, 2006; Tajudin, 2013; Garza, 2007; Offiong, 2013) and to make the guests more open to him, but when Daniel Mananta talks to him, he also uses informal languages because he and Boy William has a close relationship and because Daniel Mananta is invited as a friend to Nebeng Boy by Boy William.

This research finding also found that the code choice is also affected by other social factors such as the background of the speaker and the profession of the speaker. President Jokowi always uses Bahasa Indonesia in the informal variety and does not mix or switch to English like the other guests. This is to show his background as the President of Indonesia and to show his 
nationalism to the country (Hughes, 2006; Tajudin, 2013; Garza, 2007; Offiong, 2013). Moreover, Najwa Shihab, a famous presenter, even though she is older than Boy William she addresses herself as "Aku" to Boy William meanwhile, Merry Riana addresses herself as "Saya" which show contrast that profession and background affect the choice of language.

The other research conducted before also found that the code choice is also affected by the situation of the conversation, the topic, the function of the conversation (Salsabila 2018, Hughes, 2006, Darmiasih, 2019). These factors are also shown in the analysis of the fist sub-chapter IV where most of the guests speak informally because of the situation and the topic of the conversation which naturally affect them to choose informal language varieties.

\section{Conclusion}

The types of code choice used by the participants in Nebeng Boy are Bahasa Indonesia, switching to English, mixing with English, English, switching to Bahasa Indonesia, Mixing with Bahasa Indonesia. The percentage of code choice used by the participants are $(40,5 \%)$ Bahasa Indonesia, (10,5\%) Switching from Bahasa Indonesia to English, (23,7\%) mixing with English, $(20,6 \%)$ English, (1,6\%) switching from English to Bahasa Indonesia, and $(3,1 \%)$ mixing with Bahasa Indonesia. Bahasa Indonesia is the most dominant code used in Nebeng Boy, because Bahasa Indonesia is national language of Indonesia, and most of the participant of Nebeng Boy is Indonesian. The high percentage of English used in Nebeng Boy became the features and the characteristics of Nebeng Boy as one of YouTube content produced by Indonesian YouTubers and directed to Indonesian viewers. In this case, most of the participants of Nebeng Boy are Indonesian with fluency of English which shows that English as a prestigious language which only people with high social class and high education who can master it.

The pattern of code choice used by each of the participants are consistent. The 
participants used informal language during the conversation either in Bahasa Indonesia or English. In case of Bahasa Indonesia, the indicator or informal language variety used is the incomplete structure sentence, the use of non-standard word choices, the use of local language dialect such as Javanese and Betawi dialect, and mixing or switching to English. Similar to the informality of Bahasa Indonesia, the English used is also informal, indicated by incomplete grammatical sentence, the use of informal expression and words choices, and the mixing or switching to Bahasa Indonesia. The switching and mixing with English happened in majority of time shown by percentage above, switching and mixing in this case can be in the form of words, phrases, sentence or expressions.

Each of participants of the YouTube content "Nebeng Boy" has different characteristic and way of talking which is distinctive one to another. This phenomenon affected by some reason. In this case, the researcher found out that both of the host and the guests used informal language while talking in Nebeng Boy. However, the reason of the host in using informal language is different from the reason why the guests use informal languages. The researcher found that the host uses informal language in the vlog Nebeng Boy to make the guests are more comfortable with him and to be more open with him to talk about impersonal matters to the most personal matters. Meanwhile, for the guests, the reason why the guests chose to speak in informal language because of the situation of the event or the conversation takes place, the relationship between the guest and the host outside Nebeng Boy, the background of each guest including age and profession, and the last one is the topic that may require the participants to switch to other code. 


\section{References}

Fasold, R. (1990). The Sociolinguistics of Language. Oxford: Basil Blackwell Publisher Limited.

Fishman, J. A. (1972). The Sociology of Language. Rowley Massachusetts: Newberry House Publisher.

Fishman, J. A. (1991). Reversing Language Shift: Theoritical and Empirical Foundations of Assistance to Threatened Languages. Multilingual Matters. Ottawa: Oxford Press.

Holmes, J. (1992). An Introduction to Sociolinguistics. London: Longman.

Hymes, D. (1989). Foundation in Sociolinguistics: An Ethnographic Approach. Philadelphia:

University of Pennsylvania Press.

Magfiroh, L. (2018). An Analysis on Form, Function, And Reason Of Code-Switching and CodeMixing Used In Vlog of Shirin Al Athrus. Salatiga: IAIN Salatiga.

Mackey, W. (2000). The Description of bilingualism. London: Routledge.

Mackey, W. F. (1972). Bilingual Education in a Binational School: A Study of Equal Language Maintenance Through Free Alternation.

Primayanda, Atria (2019) THE ROLE OF CODE SWITCHING PHENOMENA IN A YOUTUBE VLOG BY SACHA STEVENSON. Undergraduate thesis, Diponegoro University.

Yusmawati, Cut Intan Lestari, Nurul Hidayah. (2018). Language Choice Used by Chinese Family in Langsa. Language Literacy: Journal of Linguistics, Literature and Language Teaching Volume 2, Number 2, 159-166. 